\title{
Heavy Metals in Rock Oyster Saccostrea cucullata Collected from Sungai Tapai and Pantai Lido, Peninsular Malaysia: An Insight from Health Risk Assessment
}

\author{
Chee Kong Yap'*, Wing Sam Lo', Wan Hee Cheng', Rosimah Nulit', Mohd Hafiz Ibrahim', Shih Hao \\ Tony Peng ${ }^{3}$, Chee Wah Yap ${ }^{4}$, Moslem Sharifinia ${ }^{5}$, Alireza Riyahi Bakhtiari ${ }^{6}$ and Salman Abdo Al-Shami \\ 'Department of Biology, Faculty of Science, University Putra Malaysia, 43400 UPM, Serdang, Selangor, Malaysia. \\ ${ }^{2}$ Inti International University, Persiaran Perdana BBN, Nilai, Negeri Sembilan, Malaysia. \\ ${ }^{3}$ All Cosmos Bio-Tech Holding Corporation, PLO650, Jalan Keluli, Pasir Gudang Industrial Estate, 81700 Pasir Gudang, Johor, Malaysia. \\ ${ }^{4}$ MES SOLUTIONS, 22C-1, Jalan BK 5A/2A, Bandar Kinrara, 47100 Puchong, Selangor, Malaysia. \\ ${ }^{5}$ Shrimp Research Center, Iranian Fisheries Science Research Institute, Agricultural Research, Education and Extension Organization (AREEO), \\ Bushehr, Iran. \\ ${ }^{6}$ Department of Environmental Sciences, Faculty of Natural Resources and Marine Sciences, Tarbiat Modares University, Noor, Mazandaran, \\ Iran. \\ ${ }^{7}$ Indian River Research and Education Center, IFAS, University of Florida, Fort Pierce, FL 34945, USA.
}

*Address for Correspondence: Chee Kong Yap, Department of Biology, Faculty of Science, University Putra Malaysia, 43400 UPM, Serdang, Selangor, Malaysia. Email: yapckong@hotmail.com; yapchee@upm.edu.my

Received: 27 May 2020; Accepted: 25 July 2020; Published: 29 July 2020

Citation of this article: Yap CK, Lo WS, Cheng WH, Nulit R, Ibrahim MH, et al. (2020) Heavy Metals in Rock Oyster Saccostrea cucullata Collected from Sungai Tapai and Pantai Lido, Peninsular Malaysia: An Insight from Health Risk Assessment. Rea Int Journal of Energy Environmental sci. 1(1): 005-010. DOI: 10.37179/rijees.000002.

Copyright: (C) 2020 Yap CK, et al. This is an open access article distributed under the Creative Commons Attribution License, which permits unrestricted use, distribution, and reproduction in any medium, provided the original work is properly cited.

Keywords: Oyster, Saccostrea cucullata, heavy metals, Malaysia.

\section{Introduction}

The rock oyster, Saccostrea cucullata is a filter-feeder bivalve (Tack and Polk, 1996) that lives on trunks and roots of mangroves and rocky substrate (Tack et al., 1992). In general, oysters are the accumulators of heavy metals (Yap et al., 2011a) and hyper accumulators for Zn (Silva et al., 2006; Yap et al., 2011b; Wang and Lu, 2017).

Numerous studies on heavy metals in the oysters are reported in the literature. In Malaysia, bioaccumulation of heavy metals in oysters was reported by Najiah et al. $(2008)$ and Lim et al. $(1995,1998)$ on Crassaostrea iredalei; Saed et al. (2004) on Isognomon alatus and Lim et al. $(1995,1998)$ on C. belcheri. Studies on the uses of oysters as biomonitors of heavy metal contamination were reported from Natal Brazil (Silva et al., 2006), and US coast (O'connor and Lauenstein, 2006).
The distributions of heavy metals in the different organs or tissues of intertidal molluscs have been well reported in the literature. These published studies included the green-lipped mussel Perna viridis (Yap et al., 2012, 2006; Yap, 2018), clam Polymesoda erosa (Yap et al., 2014a), mangrove snail Nerita lineata (Yap and Cheng, 2013; Yap et al., 2014), cockle Anadara granosa (Yap and Lo, 2013), and mudflat snail Telescopium (Yap et al., 2013) and rock oyster S. cucullata (Yap et al., 2010).

However, all these citations never discussed the human health risk assessment (HHRA) using Target Hazard Quotient (THQ) in the specific organ or tissues investigated. All of the above interpretations of results were focused on metal bio availabilities and bio monitoring points of view (Rainbow, 1995). The objective of the present study is to determine the HHRA of $\mathrm{Cd}, \mathrm{Cu}, \mathrm{Fe}, \mathrm{Ni}, \mathrm{Pb}$ and $\mathrm{Zn}$ in the edible soft tissues of S. cucullata collected from Sg. Tapai and Pantai Lido in 2008 . 
Citation: Kong Yap C (2020) Heavy Metals in Rock Oyster Saccostrea cucullata Collected from Sungai Tapai and Pantai Lido, Peninsular Malaysia: An Insight from Health Risk Assessment. Rea Int J of Ener Environ sci.. 1(1): 005-010.

DOI: $10.37179 /$ rijees.000002.

\section{Materials and Methods}

About 25-30 of the oysters, S. cucullata from Sg. Tapai (Kelantan; sampled on 13 May 2008) and Pantai Lido (near Danga Bay, Johor; sampled on 3 May 2008) (Figure 1) was used for the metal analysis. The sampling sites description and some in-situ surface water parameters are given in (Table 1).

The identification of the oyster species was based on the book authored by Takashi (2000), and the Malaysia Fisheries Directory (2005) by Department of Fisheries Malaysia. The shell lengths $(\mathrm{cm})$ of the oysters ranged from 2.82-5.54 and 6.92-9.49 for Sg. Tapai and Pantai Lido, respectively.

The oyster shell widths $(\mathrm{cm})$ ranged from 3.30-6.10 and 7.63-10.6 for Sg. Tapai and Pantai Lido, respectively. The oyster shell heights $(\mathrm{cm})$ ranged from 1.08-2.27 and 3.13-4.76 for Sg. Tapai and Pantai Lido, respectively.

The total soft tissue wet weight and dry weight of the two populations ranged from 0.84-4.11g (mean: $2.24 \mathrm{~g}$ ) and 0.11$0.91 \mathrm{~g}$ (mean: $0.42 \mathrm{~g}$ ), respectively. Therefore, the conversion factor $(0.42 / 2.24)$ of 0.19 was used to convert the dry weight into wet weight basis. The water contents of the two populations ranged from 77.0$87.5 \%$ (mean: $81.3 \%$ )

The oysters were dissected from the shells, and they were pooled into muscle, mantle, gill and remainder. The samples were dried at $60^{\circ} \mathrm{C}$ until constant dry weights. They were digested in concentrated $\mathrm{HNO}_{3}$ (Analar grade, $\mathrm{BDH} 69 \%$ ). They were placed in a hot-block digester for 1 hour $\left(40^{\circ} \mathrm{C}\right)$ and increased to $140^{\circ} \mathrm{C}$ for at least 3 hours (Yap et al., 2003a). After dilution and filtration, they were determined

Table 1: Sampling details and some water parameters for all sampling sites.

\begin{tabular}{|c|c|c|c|c|c|c|}
\hline No. & $\begin{array}{l}\text { Sampling Site } \\
\text { (GPS) }\end{array}$ & Description & Temp & Cond & Sal & DO \\
\hline 1. & $\begin{array}{c}\text { Sg. Tapai } \\
\left(6^{\circ} 12^{\prime} 45.76 ” \mathrm{~N},\right. \\
\left.102^{\circ} 08^{\prime} 38.02^{\prime \prime} \mathrm{E}\right)\end{array}$ & $\begin{array}{c}\text { Recreational } \\
\text { beach and } \\
\text { agricultural area }\end{array}$ & $\begin{array}{l}30.1 \pm \\
0.001\end{array}$ & $\begin{array}{l}40419 \\
\pm 2.39\end{array}$ & $\begin{array}{c}23.2 \pm \\
0.001\end{array}$ & $\begin{array}{l}1.20 \pm \\
0.001\end{array}$ \\
\hline 2. & $\begin{array}{c}\text { Pantai Lido (Sg. } \\
\text { Danga) } \\
\text { (N 01 } 28.001^{\prime} \mathrm{N} \text {; } \\
\left.103^{\circ} 43.618^{\prime} \mathrm{E}\right)\end{array}$ & $\begin{array}{c}\text { Urban and } \\
\text { agricultural areas }\end{array}$ & $\begin{array}{l}30.5 \pm \\
0.001\end{array}$ & $\begin{array}{l}30815 \\
\pm 4.01\end{array}$ & $\begin{array}{l}17.0 \pm \\
0.001\end{array}$ & $\begin{aligned} & 2.14 \\
\pm & 0.001\end{aligned}$ \\
\hline
\end{tabular}

Note: $\operatorname{Temp}\left({ }^{\circ} \mathrm{C}\right)=$ Temperature; Cond= Conductivity $(\mu \mathrm{s} / \mathrm{cm}) ; \mathrm{DO}=$ Dissolved oxygen (mg/L).

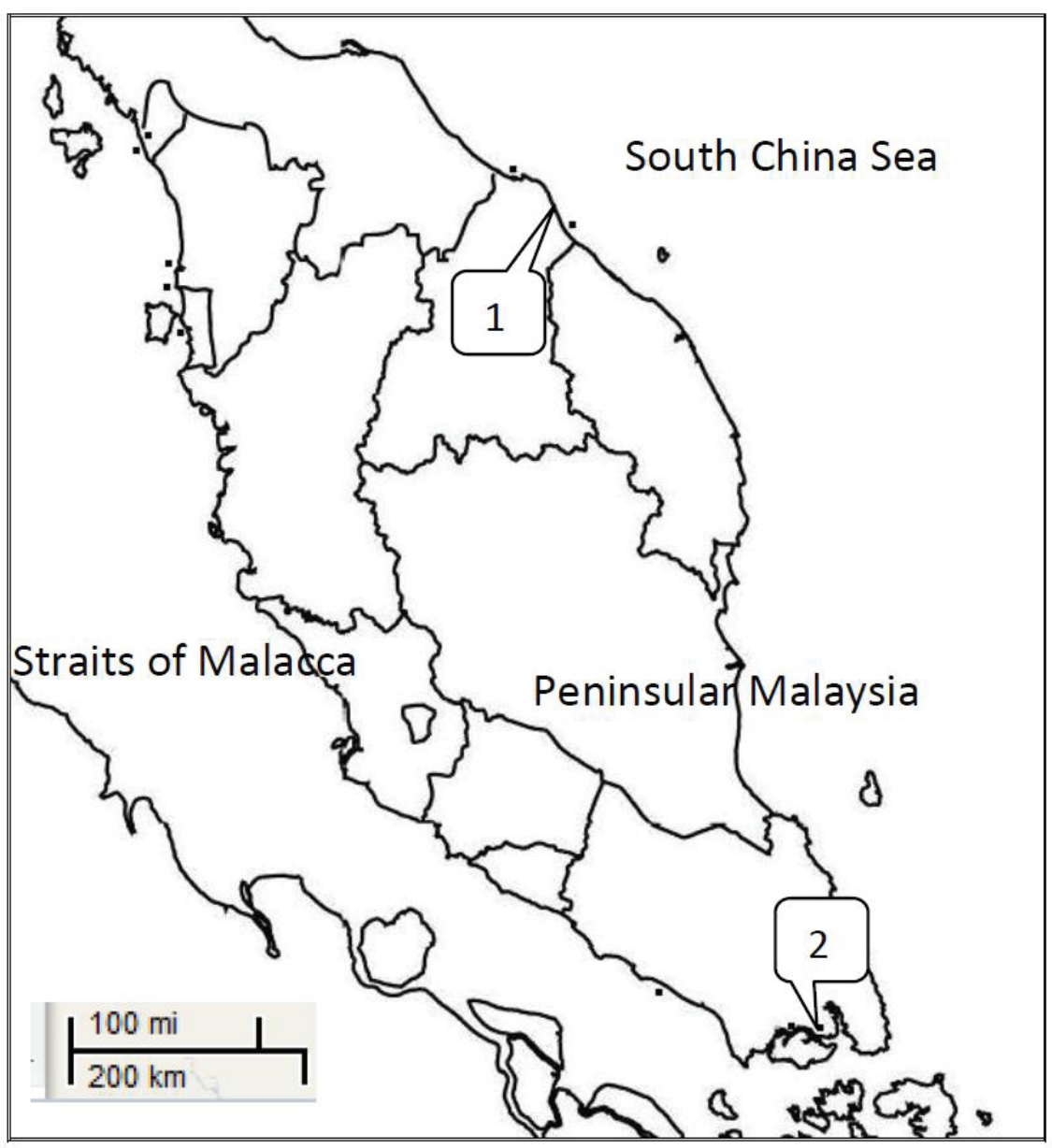

Figure 1: Map showing the sampling sites for Saccostrea cucullata in Peninsular Malaysia (1 = Sg. Tapai; $2=$ Pantai Lido). 
Citation: Kong Yap C (2020) Heavy Metals in Rock Oyster Saccostrea cucullata Collected from Sungai Tapai and Pantai Lido, Peninsular Malaysia: An Insight from Health Risk Assessment. Rea Int J of Ener Environ sci.. 1(1): 005-010.

DOI: $10.37179 /$ rijees.000002.

for $\mathrm{Cd}, \mathrm{CU}, \mathrm{Fe}, \mathrm{Ni}, \mathrm{Pb}$ and $\mathrm{Zn}$ by using an air-acetylene flame Atomic Absorption Spectrophotometer (AAS) Perkin-Elmer Model Analyst 800.

For quality control and quality assurance, all glassware and equipment used were acid-washed. Besides, procedural blanks and quality control samples made from standard solutions for all the six metals were analyzed to check for sample accuracy. The metal percentages of recoveries for the metals were between $80-110 \%$. The analytical procedures for the samples were also checked with the Certified Reference Material (CRM) dogfish liver (DOLT-3, National Research Council Canada). The recoveries for the CRM were satisfactory being between $89-103 \%$.

\section{Health Risk Assessment}

To assess a once-or long-term potential hazardous exposure to the six heavy metals through consumption of oysters (USEPA, 1989), the Estimated Daily Intake (EDI) and THQ values were calculated by using the following formulas:

\section{$\mathrm{EDI}=(\mathrm{Mc} \mathrm{x}$ consumption rate $) /$ body weight}

\section{$\mathrm{THQ}=\mathrm{EDI} / \mathrm{RfD}$}

Where $\mathrm{Mc}$ is the metal concentration $(\mathrm{mg} / \mathrm{kg})$ in the oyster soft tissue (converted wet weight); body weight for Malaysian adult was $62 \mathrm{~kg}$ and consumption rate as $41 \mathrm{~g} /$ day for Malaysian adults (Nurul Izzah et al., 2016). The metal concentrations in $\mu \mathrm{g} / \mathrm{g}$ dry weight were converted into wet weight basis by using a conversion factor of 0.19 for the four different edible soft tissues of oysters.

The oral reference dose (RFD) was used to compare with the EDI ( $\mu \mathrm{g} / \mathrm{kg}$ wet weight/day) of metals in the oysters. The RFD ( $\mu \mathrm{g} /$ $\mathrm{kg}$ wet weight/day) values used in this study were Cd: 1.00 ; $\mathrm{Cu}$ : 40.0; Fe: 700, Ni: 20 and Zn: 300, provided by the EPA's Integrated Risk Information System online database (IRIS) (IRIS, 2014). Since RFD for Pb was not available according to the EPA's IRIS (IRIS, 2014). The present study employed the RFD as $3.50 \mu \mathrm{g} / \mathrm{kg}$ wet weight/day, as suggested by a former study by USEPA $(2000,2008)$.
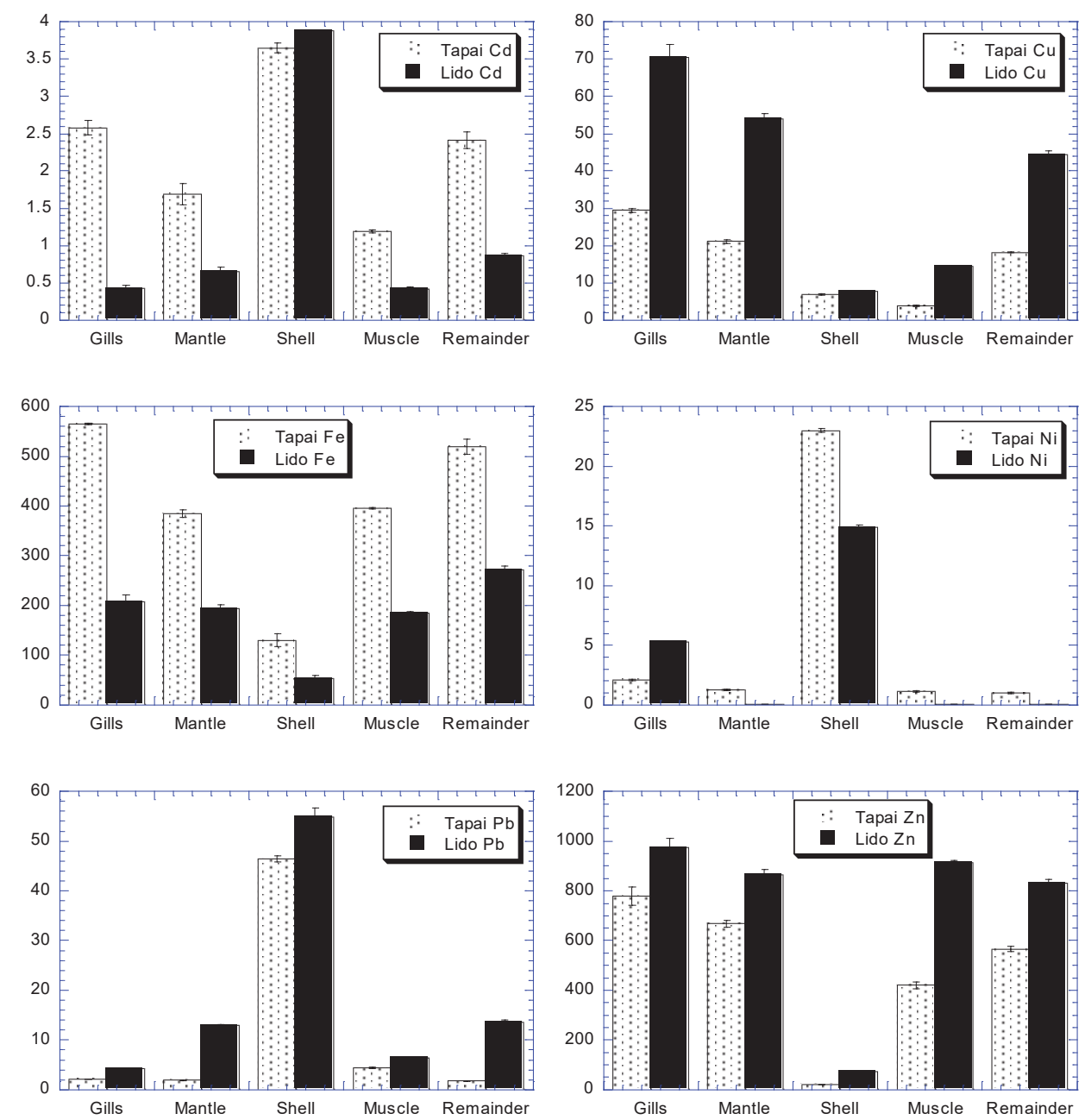

Figure 2: Heavy metal concentrations (mean $\pm \mathrm{SE}, \mu \mathrm{g} / \mathrm{g} \mathrm{dw}$ ) in the different parts of oyster collected from Pantai Lido and Sg. Tapai. 
Citation: Kong Yap C (2020) Heavy Metals in Rock Oyster Saccostrea cucullata Collected from Sungai Tapai and Pantai Lido, Peninsular Malaysia: An Insight from Health Risk Assessment. Rea Int J of Ener Environ sci.. 1(1): 005-010.

DOI: $10.37179 /$ rijees.000002.

Table 2: Values of Estimated Daily Intake (EDI) and Target Hazard Index (THQ) in the oysters collected from Sg. Tapai and Pantai Lido.

\begin{tabular}{|c|c|c|c|c|c|c|c|c|c|c|c|c|}
\hline \multicolumn{3}{|c|}{$C d$} & \multicolumn{2}{|l|}{$\mathrm{Cu}$} & \multicolumn{2}{|l|}{$\mathrm{Fe}$} & \multicolumn{2}{|l|}{$\mathrm{Ni}$} & \multicolumn{2}{|l|}{$\mathrm{Pb}$} & \multicolumn{2}{|l|}{$\mathrm{Zn}$} \\
\hline Tapai & EDI & $\mathrm{THQ}$ & EDI & $\mathrm{THQ}$ & EDI & $\mathrm{THQ}$ & EDI & $\mathrm{THQ}$ & EDI & $\mathrm{THQ}$ & EDI & THQ \\
\hline Gills & 0.32 & 0.32 & 3.71 & 0.09 & 70.9 & 0.10 & 0.26 & 0.013 & 0.27 & 0.08 & 98.0 & 0.33 \\
\hline Mantle & 0.21 & 0.21 & 2.65 & 0.07 & 48.4 & 0.07 & 0.16 & 0.008 & 0.24 & 0.07 & 83.9 & 0.28 \\
\hline Muscle & 0.15 & 0.15 & 0.48 & 0.01 & 49.8 & 0.07 & 0.14 & 0.007 & 0.55 & 0.16 & 52.8 & 0.18 \\
\hline Remainder & 0.30 & 0.30 & 2.29 & 0.06 & 65.2 & 0.09 & 0.13 & 0.006 & 0.22 & 0.06 & 71.1 & 0.24 \\
\hline Lido & EDI & $\mathrm{THQ}$ & EDI & $\mathrm{THQ}$ & EDI & $\mathrm{THQ}$ & EDI & $\mathrm{THQ}$ & EDI & THQ & EDI & $\mathrm{THQ}$ \\
\hline Gills & 0.05 & 0.05 & 8.85 & 0.22 & 26.1 & 0.04 & 0.66 & 0.033 & 0.53 & 0.15 & 122 & 0.41 \\
\hline Mantle & 0.08 & 0.08 & 6.78 & 0.17 & 24.4 & 0.03 & 0.01 & 0.001 & 1.63 & 0.47 & 109 & 0.36 \\
\hline Muscle & 0.05 & 0.05 & 1.81 & 0.05 & 23.1 & 0.03 & 0.01 & 0.001 & 0.81 & 0.23 & 115 & 0.38 \\
\hline Remainder & 0.11 & 0.11 & 5.58 & 0.14 & 34.2 & 0.05 & 0.01 & 0.001 & 1.71 & 0.49 & 104 & 0.35 \\
\hline
\end{tabular}

Note: The metal concentrations in $\mathrm{mg} / \mathrm{kg}$ dry weight were converted into wet weight basis by using a conversion factor of 0.19 for the four different soft tissues.

\section{Results and Discussion}

The heavy metal concentrations in the shells and four different edible soft tissues of the two oyster populations are presented in Figure 2. Based on the edible soft tissues (gills, mantle, muscle and remainder), the metal concentrations $(\mu \mathrm{g} / \mathrm{g} \mathrm{dw})$ ranged from 0.42 2.58 for $\mathrm{Cd}, 3.81-70.4$ for $\mathrm{Cu}, 184-565$ for $\mathrm{Fe}, 0.08-5.28$ for $\mathrm{Ni}, 1.73$ 13.6 for $\mathrm{Pb}$, and $420-975$.

Except for $\mathrm{Pb}$, gills were found to record the highest $\mathrm{Cd}$ level among all the soft tissues. The remainder was found to have the highest $\mathrm{Pb}$ level. When compared to other soft tissues, shells recorded the highest levels of $\mathrm{Cd}, \mathrm{Ni}$ and $\mathrm{Pb}$, while the lowest levels of $\mathrm{Fe}$ and $\mathrm{Zn}$ in the shells.

In general, oyster accumulated the highest levels of $\mathrm{Zn}$ in comparison to $\mathrm{Cd}, \mathrm{Cu}, \mathrm{Fe}, \mathrm{Ni}$, and $\mathrm{Pb}$. This is supported by the study reported for S. cucullata collected from Penang coastal waters (Yap et al., 2010). Abhilash et al. (2013) assessed the levels of $\mathrm{Zn}, \mathrm{Cu}, \mathrm{Fe}$, $\mathrm{Pb}$ and $\mathrm{Ni}$ in S. cucullata, around Port Blair, India. Zinc was found to be the highest concentrated trace metal in all the five stations, probably due to the role of several $\mathrm{Zn}$ metalloenzymes in the oyster shell mineralization (Abhilash et al., 2013).

$\mathrm{Zn}$ is believed to be accumulated from the solute phase proportionally to the ambient $\mathrm{Zn}$ concentrations (Chong and Wang, 2000). This could be due to its high assimilation efficiency, and low rate constants of loss (Luoma and Rainbow, 2005).

According to Szefer et al. (2007), oysters are known to be exceptional accumulators of $\mathrm{Zn}$ and $\mathrm{Cu}$. Similar elevated $\mathrm{Zn}$ levels in the oysters can be found in the literature for S. cucullata (Blackmore, 2001), pearl oysters (Pinctada radiata) (Gokoglu et al. (2006), and flat-tree oyster I. alatus (Saed et al., 2004).

In general, higher concentrations of $\mathrm{Cu}, \mathrm{Pb}$ and $\mathrm{Zn}$ were found in the Pantai Lido population than Sg. Tapai population (Figure 2). Meanwhile, generally higher concentrations of $\mathrm{Cd}, \mathrm{Fe}$ and Ni were found in the different parts of oyster from Sg. Tapai than Pantai Lido population. This indicated that Pantai Lido had higher bio availabilities of $\mathrm{Cu}, \mathrm{Pb}$ and $\mathrm{Zn}$ than $\mathrm{Sg}$. Tapai while $\mathrm{Sg}$.

Tapai had higher bio availabilities of $\mathrm{Cd}, \mathrm{Fe}$ and Ni than Pantai Lido population. By referring to the sampling site description, Pantai Lido is an urban, aquaculture area besides being a boat jetty and potentially receiving municipal wastes (Yap et al., 2006), while, Sg. Tapai is a recreational beach and agricultural area. Heavy metal bio availabilities found in these locations could be due to the anthropogenic activities found in the sites.

From the present study, the metal concentrations $(\mu \mathrm{g} / \mathrm{g}$ dry weight) in the oyster muscles from the two populations ranged from 420-912 for $\mathrm{Zn}, 3.81-14.4$ for $\mathrm{Cu}$, and 4.39-6.42 for $\mathrm{Pb}$. Chakraborty and Mitra A (2017) reported the metal concentrations ( $\mu \mathrm{g} / \mathrm{g}$ dry weight) muscles of $S$. cucullata collected from Sagar Island, West Bengal, ranging from 187-217 for $\mathrm{Zn}, 102-133$ for $\mathrm{Cu}$, and 13.1-17.9 for $\mathrm{Pb}$. Lee et al.

(2015) suggested that the adductor muscle of Atrina japonica displayed an essential role in the energy loading. Uddin et al. (2007) reported that the weight loss of the muscle of scallop during the spawning was related to energy storage. Baik et al. (2001) reported that the adductor muscle of A. japonica had higher glycogen content than those in the visceral mass.

Values of EDI and THQ for the six metals in the two populations are given in Table 2. Overall, the values of EDI ranged from 00.050.32 for $\mathrm{Cd}, 0.48-8.85$ for $\mathrm{Cu}, 23.1-70.9$ for $\mathrm{Fe}, 0.01-0.66$ for $\mathrm{Ni}, 0.22$ 1.71 for $\mathrm{Pb}$, and $52.8-122$ for $\mathrm{Zn}$. The values of THQ for all the six metals are all below 1.0.

This means that the daily consumption of oysters collected from Sg. Tapai and Pantai Lido would not likely result in adverse health effects during a lifetime in a human population (Bogdanovic et al., 2014). This also indicated that the two oyster populations from the six sites are safe, with no non-carcinogenic effects of the six metals, for consumption at least based the sampling period.

\section{Conclusion}

This study determined the concentrations of six heavy metals in the shells and four edible soft tissues of $S$. cucullata collected from Sg. Tapai and Pantai Lido obtained in 2008. Higher bio availabilities of $\mathrm{Cu}, \mathrm{Pb}$ and $\mathrm{Zn}$ to $S$. cucullata were found in the Pantai Lido population; meanwhile, Sg. Tapai had higher bio availabilities of $\mathrm{Cd}$, $\mathrm{Fe}$ and $\mathrm{Ni}$ to the oyster population.

For HHRA, the THQ values of all the six metals are below than 1.0. These values indicated that the edible soft tissues of oysters would cause no non-carcinogenic risk of $\mathrm{Cd}, \mathrm{Cu}, \mathrm{Fe}, \mathrm{Ni}, \mathrm{Pb}$ and $\mathrm{Zn}$ to the 
Citation: Kong Yap C (2020) Heavy Metals in Rock Oyster Saccostrea cucullata Collected from Sungai Tapai and Pantai Lido, Peninsular Malaysia: An Insight from Health Risk Assessment. Rea Int J of Ener Environ sci.. 1(1): 005-010.

DOI: $10.37179 /$ rijees.000002.

consumers. Therefore, rock oysters are safe to be consumed based on the samples collected in 2008 .

\section{Acknowledgement}

The financial support provided through the Research University Grant Scheme (RUGS), [Vote no: 91229], by University Putra Malaysia is highly acknowledged.

\section{References}

1. Abhilash KR, Gireeshkumar TR, Venu S, Raveendran TV (2013) Bio concentration of trace metals by Saccostrea cucullata (von Born 1778) from Andaman waters. Ind. J. Geo-Mar. Sci 42: 326-330. Link: https://bit. ly/2DcPRxq

2. Baik SH, Kim KJ, Chung EY, Choo JJ, Park KH (2001) Seasonal variations in biochemical components of the visceral mass and adductor muscle in the pen shell, Atrina pectinata. Fish. Aquat. Sci 4: 18-24. Link: https://bit.ly/2D8G1MY

3. Blackmore G (2001) Interspecific variation in heavy metal body concentrations in Hong Kong marine invertebrates. Environ. Pollut 114: 303-311. Link: https://bit.ly/39wqimQ

4. Bogdanovic T, Ujevic I, Sedak M, Listes E, Simat, et al. (2014) As, Cd, Hg and $\mathrm{Pb}$ in four edible shellfish species from breeding and harvesting areas along the eastern Adriatic Coast, Croatia. Food Chem 146: 197-203. Link: https://bit.ly/2PbVvmd

5. Chakraborty S, Mitra A (2017) Concentrations of heavy metals in edible dominant oyster (Saccostrea cucullata) inhabiting Sagar Island, West Bengal. J. Fisheries Livest. Prod 5: 238. Link: https://bit.ly/2OY457Z

6. Chong K, Wang WX (2000) Assimilation of cadmium, chromium, and zinc by the green mussel Perna viridis and the clam Ruditapes philippinarum. Environ. Toxicol. Chem 19: 1660-1667. Link: https://bit.ly/3f2QTsZ

7. Department of Fisheries Malaysia (2005) Malaysia Fisheries Directory, 2005 06. Acean Medialine (M) Sdn. Bhd 56-57. Link: https://bit.ly/2WW5mAv

8. Gokoglu N, Gokoglu M, Yerlikaya P (2006) Seasonal variations in proximate and elemental composition of pearl oyster (Pinctada radiata, Leach, 1814) J Sci Food Agric 86: 2161-2165. Link: https://bit.ly/3f3mWZN

9. (2014) IRIS (Integrated risk information system) US Environmental Protection Agency. Link: https://bit.ly/3hJkzgf

10. Lee YJ, Choi KS, Lee DS, Lee WC, Park HJ, et al. (2015) The role of the adductor muscle as an energy storage organ in the pen shell Atrina japonica (Reeve, 1858) J. Molluscan Stud 81: 502-511. Link: https://bit.ly/39HOdQB

11. Lim PE, Lee CK, Din Z (1995) Accumulation of heavy metals by cultures oysters from Merbok Estuary, Malaysia. Mar. Pollut. Bull. 31: 420-423. Link: https://bit.ly/2WX9nVm

12. Lim PE, Lee CK, Din Z (1998) The kinetics of bioaccumulation of zinc, copper lead and cadmium by oysters (Crassostrea iredalei and C. belcheri) under tropical field conditions. Sci. Tot. Environ 216: 147-157. Link: https://bit. ly/2D8Sb8A

13. Luoma SN, Rainbow PS (2005) Why is metal bioaccumulation so variable? Biodynamic as a unifying concept. Environ. Sci. Tech 39: 1921-1931. Link: https://bit.ly/3jlpdx4

14. Najiah M, Nadirah M, Lee KL, Lee SW, Wendy W, et al. (2008) Bacteria flora and heavy metals in cultivated oyters Crassostrea iredalei of Setiu Wetland, East Coast Peninsular Malaysia. Vet. Res. Comm 32: 377-381. Link: https:// bit.ly/3g2nkZK

15. Nurul Izzah A, Wan Rozita WM, Tengku Rozaina TM, Cheong YL, Siti Fatimah D, et al. (2016) Fish consumption pattern among adults of different ethnics in Peninsular Malaysia. Food Nutr. Res 60: 32697. Link: https://bit. ly/2X1DKdr
16. O'Connor TP, Lauenstein GG (2006) Trends in chemical concentrations in mussels and oysters collected along the US coast: Update to 2003. Mar. Environ. Res 62: 261-285. Link: https://bit.ly/2WXAlH4

17. Rainbow PS (1995) Bio monitoring of heavy metal availability in the marine environment. Mar. Pollut. Bull 31: 183-192. Link: https://bit.ly/300U6r4

18. Silva CAR, Smith BD, Rainbow PS (2006) Comparative biomonitors of coastal trace metal contamination in tropical South America. Mar. Environ. Res 61: 439-455. Link: https://bit.ly/39uls8y

19. Szefer P, Ikuta K, Kushiyama S, Frelek K, Geldon J (2007) Distribution of Trace Metals in the Pacific Oyster, Crassostrea gigas, and Crabs from the East Coast of Kyushu Island, Japan. Bull. Environ. Contam. Toxicol 58: 108114. Link: https://bit.ly/2CUu2CG

20. Tack JF, Polk $P$ (1996) The uptake of colloidal melanin from seawater by marine bivalves. Mar. Ecol. 17: 543-548. Link: https://bit.ly/3g3XF2X

21. Tack JF, Vanden BE, Polk P (1992) Ecomorphology of Saccostrea cucullata (Born, 1778) (Ostreidae) in mangrove creek (Gazi, Kenya). Hydrobiol 247: 109-117. Link: https://bit.ly/39ud2z4

22. Takashi O (2000) Marine molluscs in Japan Tokai University, Japan. Tokai University Press, Japan. Link: https://bit.ly/2Ehtoj2

23. Uddin MJ, Park KI, Kang DH, Park YJ, Choi KS (2007) Comparative reproductive biology of Yezo scallop, Patinopecten yessoensis, under two different culture systems on the east coast of Korea. Aquacul 265: 139-147. Link: https://bit.ly/2BzvmKP

24. (1989) USEPA (US Environmental Protection Agency) Guidance manual for assessing human health risks from chemically contaminated, fish and shellfish. EPA-503/8-89-002. USEPA, Washington DC. Link: https://bit. ly/3fbA4w9

25. (2000) USEPA (US Environmental Protection Agency) Risk-Based Concentration Table. Philadelphia PA: USEPA, Washington, DC. Link: https://bit.ly/2CTSGDv

26. (2008) USEPA (US Environmental Protection Agency) Integrated Risk Information System. CRC. Link: https://bit.ly/3hKWOop

27. (1990) USFDA (Food and Drug Administration of the United States) US Food and Drug Administration Shellfish Sanitation Branch, Washington, D.C. Link: https://bit.ly/300lwx3

28. Wang WX, Lu G (2017) Heavy Metals in Bivalve Mollusks. 553-594 Link: https://bit.ly/3jMgGZR

29. Yap CK, Noorhaidah A, Tan SG, Soo (2013) Relationships of copper concentrations between the different soft tissues of Telescopium and the surface sediments collected from tropical intertidal areas. Int. J. Chem 5 : 8-19. Link: https://bit.ly/2X1DXNJ

30. Yap CK (2018) Selected organs of marine mussels as accurate biomonitors of metal bioavailability and contamination in the coastal waters: Challenges. EC Phamacol Toxicol. 6: 528-534. Link: https://bit.ly/2WZPOfs

31. Yap CK, Cheng WH (2013) Distributions of heavy metal concentrations in different tissues of the mangrove snail Nerita lineata. Sains Malays 42: $597-$ 603. Link: https://bit.ly/3f1lKGo

32. Yap CK, W.S Lo (2013) Metal concentrations in Anadara granosa collected from intertidal mudflats on the west coast of peninsular Malaysia. J. Sust. Sci. Manage. 8: 11-21. Link: https://bit.ly/2WXLdKu

33. Yap CK, Edward FB, Tan SG (2014) Concentrations of heavy metals in different tissues of the bivalve Polymesoda erosa: Its potentials as a biomonitor and food safety concern. Pertanika J. Trop. Agric. Sci. 37: $19-$ 38. Link: https://bit.ly/304yrMh

34. Yap CK, Ismail A, Tan SG (2003) Mercury concentrations of the surface sediment of the intertidal area along the west coast of Peninsular Malaysia. Toxicol. Environ. Chem 85: 13-21. Link: https://bit.ly/3jL8MQn 
Citation: Kong Yap C (2020) Heavy Metals in Rock Oyster Saccostrea cucullata Collected from Sungai Tapai and Pantai Lido, Peninsular Malaysia: An Insight from Health Risk Assessment. Rea Int J of Ener Environ sci.. 1(1): 005-010.

DOI: $10.37179 /$ rijees.000002.

35. Yap CK, Ismail A, Edward FB, Tan SG, Siraj SS (2006) Use of different soft tissues of Perna viridis as biomonitors of bioavailability and contamination by heavy metals ( $\mathrm{Cd}, \mathrm{Cu}, \mathrm{Fe}, \mathrm{Pb}, \mathrm{Ni}$ and $\mathrm{Zn}$ ) in a semi-enclosed intertidal water, the Johore Straits. Toxicol. Environ. Chem. 88: 683-695. Link: https:// bit.ly/30KCZ9K

36. Yap CK, Mohd Nasir S, Edward FB, Tan SG (2012) Anthropogenic inputs of heavy metals in the east part of the Johore Straits as revealed by their concentrations in the different soft tissues of Perna viridis (L.). Pertanika J. Trop. Agric. Sci. 35: 827-834. Link: https://bit.ly/2WZq2b0

37. Yap CK, Mohd Ruszaidi S, Cheng WH (2010) Different tissues of rock oyster Saccostrea cucullata as biomonitors of trace metal bioavailability's in the
Penang coastal waters, Malaysia. Res. J. Chem. Environ 14: 17-21. Link: https://bit.ly/39xTgCW

38. Yap CK, Azmizan AR, Hanif MS (2011) Bio monitoring of trace metals (Fe, $\mathrm{Cu}$ and $\mathrm{Ni}$ ) in the mangrove area of Peninsular Malaysia, using different soft tissues of flat-tree oyster Isognomon alatus. Wat. Air Soil Poll 218: 19-36. Link: https://bit.ly/3hGI7mc

39. Yap CK, Azmizan AR, Hanif MS, Tan SG (2011) Use of different tissues of flat-tree oyster Isognomon alatus as biomonitors of bioavailabilities and contamination by $\mathrm{Zn}$ in the mangrove area of Peninsular Malaysia. J. Sust. Sci. Manage 6: 230-239. Link: https://bit.ly/2D5TuoG 